\title{
Determinants of neonatal mortality in a municipality of the Zona da Mata in Pernambuco*
}

\section{Determinantes da mortalidade neonatal em município da Mata Pernambucana \\ Determinantes de la mortalidad neonatal en el municipio de la Zona da Mata Pernambucana}

How to cite this article:

Souza BFN, Sousa NFC, Sette GCS, Lima APE, Leal LP, Holanda ER. Determinants of neonatal mortality in a municipality of the Zona da Mata in Pernambuco. Rev Esc Enferm USP. 2021;55:e03726. doi: https://doi.org/10.1590/S1980-220X2020015003726

Bruno Felipe Novaes de Souza ${ }^{1}$

Nayara Francisca Cabral de Sousa ${ }^{1}$

(iD) Gabriela Cunha Schechtman Sette $^{2}$

D Ana Paula Esmeraldo Lima ${ }^{2}$

Luciana Pedrosa Leal ${ }^{1}$

Eliane Rolim de Holanda ${ }^{1}$

* Extracted from the dissertation: "Determinantes socioespaciais da mortalidade infantil em um município da Mata Pernambucana”, Programa de PósGraduação em Enfermagem, Universidade Federal de Pernambuco, 2020

1 Universidade Federal de Pernambuco, Centro de Ciências da Saúde, Programa de Pós-

Graduação em Enfermagem, Recife, PE, Brazil.

${ }^{2}$ Universidade Federal de Pernambuco,

Centro de Ciências da Saúde, Departamento

de Enfermagem, Recife, PE, Brazil.

\section{ABSTRACT}

Objective: To analyze the determinants associated with neonatal mortality in a municipality in the Zona da Mata of Pernambuco state. Method: Cross-sectional and analytical study, carried out in the city of Vitória de Santo Antão, Pernambuco. All child deaths reported by the municipality to the Brazilian Mortality Information System between 2011 and 2018 were analyzed. Data were categorized and organized in three dimensions to be subjected to descriptive, bivariate statistics and hierarchical Poisson regression with robust variance. Prevalence ratios were estimated, considering variables with $\mathrm{p}<0.05$ as significant. Results: The determinants associated with neonatal death were: caesarean delivery (PR 0.83; 95\% CI 0.75-0.92), birth in the city itself (PR 1.12; 95\% CI 1.01-1.25), newborn brown and black race/skin color (PR 1.13; 95\% CI 1.001.29), prematurity (PR 1.88; 95\% CI 1.79-1.97), and Apgar score $<7$ in the fifth minute (PR 1.74; 95\% CI 1.67-1.82). Conclusion: Biological characteristics such as brown and black race/skin color, prematurity, and Apgar score $<7$ in the 5 th minute after birth, as well as access to health services, such as being born in the municipality itself and not being born by caesarean delivery, were determinants associated with neonatal mortality.

\section{DESCRIPTORS}

Infant Mortality; Risk Factors; Neonatal Nursing; Pediatric Nursing; Information Systems. 


\section{INTRODUCTION}

The Child Mortality Rate (CMT) is a relevant indicator used to measure the quality of life of a population, especially regarding maternal and child health care ${ }^{(1)}$. Child mortality and its neonatal and post-neonatal components are associated with a number of socioeconomic, behavioral, and biological risk factors, which are integrated and establish a hierarchical determination of death ${ }^{(2)}$.

Although of unequal occurrence in different parts of the world, deaths of children under one year of age have shown a substantial decrease on a global scale, consistent with the recent progresses in social conditions and health services ${ }^{(3)}$. Data from the United Nations Children's Fund (Unicef) (4) indicate that the neonatal mortality rate declined to 18 deaths per 1,000 live births in 2018, from 37 in 1990, and 31 in 2000 . The global number of neonatal deaths decreased from 5.0 million in 1990 to 2.5 million in 2018.

Despite the reduction in rates, current trends predict that about 52 million children under 5 years will die between 2019 and 2030. Almost half of these deaths among children under 5 will be of newborns, but they can be prevented by improving the quality of prenatal care and specialized care during labor, delivery, and in the post-natal period for mothers and babies ${ }^{(4-5)}$.

The significant decrease in CMR was essentially due to the pattern of reduction in the post-neonatal component, which refers to deaths from the 28th to the 364th day of life. Preventive strategies such as vaccination and breastfeeding proved to be effective in facing this problem ${ }^{(6)}$.

In contrast, the neonatal component, which comprises deaths from birth to the 27 th day of life, is still a global challenge, because it is difficult to be reduced as it is directly linked to maternal and antenatal, peripartum, and delivery care conditions ${ }^{(7)}$. The number of preventable deaths in this period reaches almost $45 \%$, mainly in the first week of life ${ }^{(5)}$. Fighting this phenomenon is still a major obstacle for developing nations, such as Brazil ${ }^{(3)}$.

In Brazil, neonatal deaths accounted for $70 \%$ of the total child deaths in $2015^{(8)}$, with a greater concentration in the Northeast Region (38.3\%) $)^{(9)}$ and a lower number of deaths in the Central-West $(5.0 \%)^{(9)}$ and South (6.9\%) regions ${ }^{(9)}$. Most neonatal deaths in the Northeast occurred in the State of Pernambuco, which accounted for more than $60 \%$ of the total child deaths in this age group ${ }^{(10)}$. Much of the responsibility for facing neonatal mortality has fallen on municipalities, which shall take a leading role in the implementation of public health policies ${ }^{(11)}$.

The planning of actions making up public policies for maternal and child care shall be aligned, among other issues, with socioeconomic, behavioral, care, and biological factors associated with neonatal death. The multi-causality of neonatal deaths can be systematized according to the hierarchical model $^{(12)}$, which was one of the first models to investigate the level of association between neonatal mortality and socioeconomic determinants.

The discussion about health determinants and constraints associated with neonatal death can contribute to the planning of health promotion actions in this region and, consequently, to the improvement of the newborn's survival conditions. Thus, the study aimed to analyze the determinants associated with neonatal mortality in a municipality in the Zona da Mata region of Pernambuco.

\section{METHOD}

\section{Study TYPE}

Analytical and cross-sectional study.

\section{LOCAL}

The study was conducted in the municipality of Vitória de Santo Antão, the most populous city in the Zona da Mata of the state of Pernambuco. With an estimated population of 137,915 inhabitants for 2018, the municipality is part of the state hospital reference system for the care of high-risk pregnant women, receiving women and newborns from 22 other surrounding municipalities, and being a reference in health care for this segment of the population.

\section{Population}

The study population consisted of the infant death records of children under one year of age reported in the municipality. The sample included child deaths taking place between 2011 and 2018. This time frame was selected due to the change, in 2011, of the content of the Death Certificate (DC), which was updated to include more detailed information.

All deaths of children of women living in the municipality of Vitória de Santo Antão were included in the research. Duplicate cases were excluded and counted only once.

\section{Data collection}

Data were obtained in April 2019 at the Epidemiological Surveillance Sector of the Municipal Health Department of Vitória de Santo Antão. Secondary data from the Mortality Information System (Sistema de Informações sobre Mortalidade - SIM) and the Live Birth Information System (Sistema de Informações sobre Nascidos Vivos SINASC) were used, entered through information contained in the DC and in the Certificate of Live Births (CLB), respectively. To improve the quality of the data in terms of completeness and reliability of the variables studied, the SIM and SINASC databases were combined ${ }^{(13)}$.

First, to start the linkage of SIM and SINASC, a unifying variable was identified, namely, the CLB number; then the lookup and reference functions provided in the Microsoft ${ }^{\circledR}$ Office Excel 2010 software were used.

For the unpaired information in this phase, and to recover incomplete records by identifying a pair of information belonging to the same individual, automated routines (standardization, relationship, and combination of files) were used, based on common fields in the two databases. For this purpose, the multi-step strategy was adopted, associated with a manual review of doubtful pairs, whose blocking fields used in the first search were: mother's name and date of birth and child's sex. During the comparison, one chose to revise the mother's name and the child's birth date. For decision 
purposes, in the phase of manual inspection of the pairs, the variables analyzed were the mother's home address, the child's death date, and the year of birth.

\section{DATA ANALYSIS AND PROCESSING}

The study adopted neonatal death of newborns younger than 28 days as a dependent variable, in a dichotomous format (yes/no). The explanatory variables were grouped into three hierarchical levels, according to the adaptation of the conceptual model by Mosley and Chen ${ }^{(12)}$ proposed by Garcia, Fernandes and Traebert ${ }^{(14)}$ (Figure 1). SIM and
SINASC variables related to each hierarchical dimension were selected. The selection took place according to the clinical relevance for the investigation of neonatal death and complete filling out of the CLB and DC information contained in the database.

Based on the aforementioned conceptual model, the determinants associated with neonatal mortality are stratified in three dimensions, the most distal consisting of socioeconomic characteristics, the intermediate one consisting of maternal behaviors and care aspects, and the proximal one formed by biological factors.

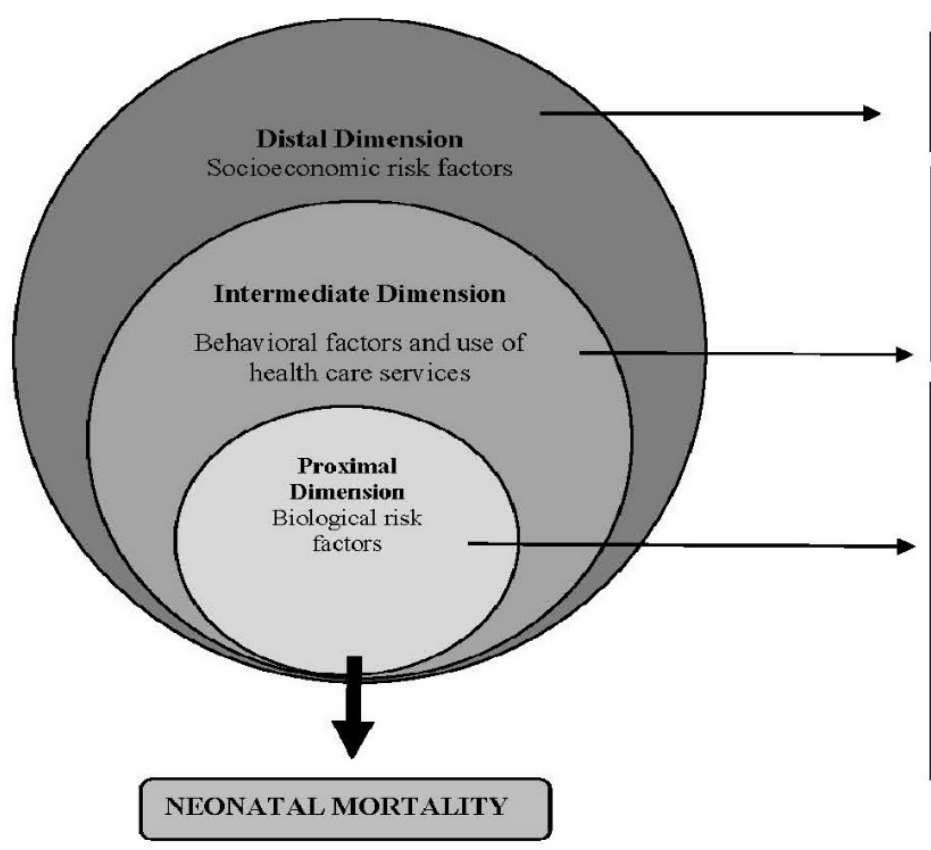

Maternal level of education

Marital status

Maternal occupation

Prenatal visits

Beginning of prenatal care in the $1^{\text {st }}$ trimester

Place of birth

Type of delivery

Induced labor

Parity

Apgar scores
Birth weight
Prematurity
Scx
Congenital anomaly
Type of pregnancy
Maternal age
Maternal and newborn race/color of skin

Source: Mosley and Chen ${ }^{(12)}$ adapted from Garcia, Fernandes and Traebert ${ }^{(14)}$.

Figure 1 - Hierarchical model for causal effects to assess the determinants associated with neonatal death.

Data were entered into the Microsoft ${ }^{\circledR}$ Office Excel 2010 software and, after typing validation by peers, statistical analysis was performed using the IBM Statistical Package for the Social Sciences (IBM SPSS), version 21.0.

The bivariate analysis was used to investigate the association between the outcome variable and determinants, through the Chi-square test and, when the assumptions of this test did not allow its application, Fisher's Exact test was used, with statistical significance of $5 \%$. The variables presenting $p \leq 0.20$ in this step were selected for multivariate analysis, according to the grouping of independent variables in the adapted hierarchical model.

Poisson regression model with robust variance was used to investigate the association of explanatory variables in the determination of neonatal death through the backward method. No variable of the distal dimension was included in the multivariate model. The variables were added based on the magnitude of association with neonatal death, as determined by the hierarchical model, and those with the highest $\mathrm{p}$-value were excluded until all of them finally presented $p<0.05$ at each level. Initially, the variables of the intermediate dimension (type of delivery, number of prenatal visits, beginning of prenatal care in the first trimester, and birth in another municipality) were incorporated into the model, with those showing higher $\mathrm{p}$-value being progressively excluded until all of them presented a $p$ value $<0.05$.

Two variables of the intermediate dimension (type of delivery and birth in another municipality) were kept in the model and five variables of the proximal dimension (newborn race/skin color, prematurity, birth weight, and Apgar scores 
in the 1 st and 5 th minutes) were added, with those with higher $\mathrm{p}$-value being excluded until all finally presented values of $\mathrm{p}<0.05$. Five variables made up the final model (type of delivery, place of birth, newborn race/skin color, prematurity, and Apgar score at the 5th minute). Variables with $\mathrm{p}<0.05$ in each dimension were considered significant. Statistical significance was determined by the Wald test, with adjusted prevalence ratios and respective 95\% confidence intervals being estimated.

\section{ETHICAL ASPECTS}

The research followed the fundamental ethical principles for the development of studies involving human beings, complying with the postulates of Resolution no. 466/2012, of the Brazilian Health Council, being approved by the Research Ethics Committee of the Universidade Federal de Pernambuco in 2019, Report no. 3.991.887.

\section{RESULTS}

Between 2011 and 2018, 16,454 births were registered in the municipality of Vitória de Santo Antão - PE and 164 child deaths were reported, with 108 deaths occurring in the neonatal period (65.9\%). In this study, the weighted neonatal mortality rate for the sample was 6.6 per one thousand live births.

Among children deaths, $25.0 \%$ of mothers were less than 19 years old, with less than 8 years of schooling $(47.5 \%)$, and half the sample did not live with their partners. Regarding the characteristics of the newborns, $57.3 \%$ were men and $76.2 \%$ were brown/black. The type of birth was vaginal in $54.3 \%$ and occurred in the municipality of the study. In this research, the municipality under analysis, despite presenting itself as a reference in maternal and child care for surrounding municipalities, redirected the assistance to labor of $42.7 \%$ of parturients to other cities.

The average length of pregnancy in cases of child deaths was $32 \pm 13$ weeks (minimum of 19 and maximum of 43 weeks), with prevalence of premature newborns (62.8\%). The average birth weight was 1,517 grams $\pm 2,140$ (minimum 300 and maximum 4,180 grams), with a higher frequency of low birth weight infants (less than 2,500 grams), which corresponded to $66.5 \%$ of the sample.

Table 1 shows the association between the blocks of variables in the hierarchical model. After the crossings, seven variables showed an association with neonatal mortality, two of which were from the intermediate dimension (type of delivery and number of prenatal consultations) and five from the proximal dimension (newborn race/skin color, prematurity, birth weight, and Apgar score in the 1st and 5th minutes). The variables corresponding to the place of birth and the beginning of prenatal care in the first semester, present in the intermediate level of the model, were selected for the multivariate analysis as they presented $\mathrm{p}<0.20$ in the bivariate analysis.

Table 1 - Neonatal mortality according to determinants of the distal, intermediate, and proximal dimensions in Vitória de Santo Antão from 2011 to 2018 - Recife, PE, Brazil, 2020.

\begin{tabular}{|c|c|c|c|}
\hline \multirow{2}{*}{ Variables } & \multicolumn{2}{|c|}{ Neonatal Death } & \multirow{2}{*}{ p-Value } \\
\hline & Yes & No & \\
\hline \multicolumn{4}{|c|}{ Distal Dimension - Socioeconomic factors } \\
\hline \multicolumn{4}{|c|}{ Maternal level of education } \\
\hline$<8$ years & $47(62.7 \%)$ & $28(37.3 \%)$ & \multirow{2}{*}{$0.683^{1}$} \\
\hline$\geq 8$ years & $52(65.8 \%)$ & $27(34.2 \%)$ & \\
\hline \multicolumn{4}{|c|}{ Mother's marital status } \\
\hline No partner & $51(63.8 \%)$ & $29(36.3 \%)$ & \multirow{2}{*}{$0.660^{1}$} \\
\hline With a partner & $51(67.1 \%)$ & $25(32.9 \%)$ & \\
\hline \multicolumn{4}{|c|}{ Occupation (outside work) } \\
\hline Yes & $39(67.2 \%)$ & $19(32.8 \%)$ & \multirow{2}{*}{$0.750^{1}$} \\
\hline No & $68(64.8 \%)$ & $37(35.2 \%)$ & \\
\hline \multicolumn{4}{|c|}{ Intermediate Dimension - Behavioral factors and use of services } \\
\hline \multicolumn{4}{|l|}{ Type of delivery } \\
\hline Caesarean & $39(52.7 \%)$ & $35(47.3 \%)$ & \multirow{2}{*}{$0.002^{1}$} \\
\hline Vaginal & $68(76.4 \%)$ & $21(23.6 \%)$ & \\
\hline \multicolumn{4}{|l|}{ Induced labor } \\
\hline Yes & $6(54.5 \%)$ & $5(45.5 \%)$ & \multirow{2}{*}{$0.518^{2}$} \\
\hline No & $96(65.8 \%)$ & $50(34.2 \%)$ & \\
\hline \multicolumn{4}{|l|}{ Parity } \\
\hline Primiparous & $24(68.6 \%)$ & $11(31.4 \%)$ & \multirow{2}{*}{$0.722^{1}$} \\
\hline Multiparous & $83(65.4 \%)$ & $44(34.6 \%)$ & \\
\hline
\end{tabular}




\begin{tabular}{|c|c|c|c|}
\hline \multirow{2}{*}{ Variables } & \multicolumn{2}{|c|}{ Neonatal Death } & \multirow{2}{*}{ p-Value } \\
\hline & Yes & No & \\
\hline \multicolumn{4}{|c|}{ Number of prenatal consultations } \\
\hline Inadequate $(<7)$ & $78(69.6 \%)$ & $34(30.4 \%)$ & \multirow{2}{*}{$0.012^{1}$} \\
\hline Adequate $(\geq 7)$ & $19(47.5 \%)$ & $21(52.5 \%)$ & \\
\hline \multicolumn{4}{|c|}{ Beginning of prenatal care in the 1 st trimester } \\
\hline Yes & $66(61.1 \%)$ & $42(38.9 \%)$ & \multirow{2}{*}{$0.157^{1}$} \\
\hline No & $26(74.3 \%)$ & $9(25.7 \%)$ & \\
\hline \multicolumn{4}{|l|}{ Place of birth } \\
\hline Vitória de Santo Antão & $51(58.6 \%)$ & $36(41.4 \%)$ & \multirow[t]{2}{*}{$0.063^{1}$} \\
\hline Other municipalities & $51(72.9 \%)$ & $19(27.1 \%)$ & \\
\hline \multicolumn{4}{|c|}{ Proximal Dimension - Biological Factors } \\
\hline \multicolumn{4}{|l|}{ Maternal age } \\
\hline$<19$ years & $27(65.9 \%)$ & $14(34.1 \%)$ & \multirow{2}{*}{$1.000^{1}$} \\
\hline$\geq 19$ years & $81(65.9 \%)$ & $42(34.1 \%)$ & \\
\hline \multicolumn{4}{|l|}{ Maternal race/skin color } \\
\hline Brown/Black & $14(60.9 \%)$ & $9(39.1 \%)$ & \multirow{2}{*}{$0.622^{1}$} \\
\hline White & $88(66.2 \%)$ & $45(33.8 \%)$ & \\
\hline \multicolumn{4}{|l|}{ Type of pregnancy } \\
\hline Single & $101(66.0 \%)$ & $52(34.0 \%)$ & \multirow{2}{*}{$0.737^{2}$} \\
\hline Twins & $6(60.0 \%)$ & $4(40.0 \%)$ & \\
\hline \multicolumn{4}{|l|}{ Newborn sex } \\
\hline Male & $64(68.1 \%)$ & $30(31.9 \%)$ & \multirow{2}{*}{$0.485^{1}$} \\
\hline Female & $44(62.9 \%)$ & $26(37.1 \%)$ & \\
\hline \multicolumn{4}{|l|}{ Newborn race/skin color } \\
\hline White & $14(43.8 \%)$ & $18(56.3 \%)$ & \multirow{2}{*}{$\mathbf{0 . 0 0 3}$} \\
\hline Brown/Black & $90(72.0 \%)$ & $35(28.0 \%)$ & \\
\hline \multicolumn{4}{|l|}{ Congenital anomaly } \\
\hline Yes & $17(73.9 \%)$ & $6(26.1 \%)$ & \multirow{2}{*}{$0.374^{1}$} \\
\hline No & $85(64.4 \%)$ & $47(35.6 \%)$ & \\
\hline \multicolumn{4}{|l|}{ Prematurity (<37 weeks) } \\
\hline Yes & $77(74.8 \%)$ & $26(25.2 \%)$ & \multirow{2}{*}{$0.001^{1}$} \\
\hline No & $29(49.2 \%)$ & $30(50.8 \%)$ & \\
\hline \multicolumn{4}{|l|}{ Birth weight } \\
\hline$<2,500$ grams & $84(77.1 \%)$ & $25(22.9 \%)$ & \multirow{2}{*}{$<0.001$} \\
\hline$\geq 2,500$ grams & $28(43.6 \%)$ & $14(56.4 \%)$ & \\
\hline Apgar score in the 1st $r$ & & & \\
\hline$<7$ & $67(82.7 \%)$ & $14(17.3 \%)$ & \\
\hline$\geq 7$ & $32(45.1 \%)$ & $39(64.9 \%)$ & $<0.001$ \\
\hline Apgar score in the 5th & & & \\
\hline$<7$ & $46(92.0 \%)$ & $4(8.0 \%)$ & $<0001$ \\
\hline$\geq 7$ & $53(52.0 \%)$ & $49(48.0 \%)$ & -0.001 \\
\hline
\end{tabular}

${ }^{1}$ Chi-square test. ${ }^{2}$ Fisher's exact test.

In the final model, variables of the intermediate and proximal dimensions remained (Table 2). In the intermediate dimension, it was observed that the type of delivery and the place of birth were associated with a higher probability of neonatal death ( $P R=0.83$ and 1.12 respectively). However, the type of delivery variable is inversely proportional to neonatal death. Thus, having been born via cesarean delivery decreased the prevalence of neonatal death when compared to children born via vaginal delivery $(\mathrm{PR}=0.83)$. In the proximal dimension, the variables race/ brown skin color/black skin color $(\mathrm{PR}=1.13)$, prematurity $(\mathrm{PR}=1.88)$, and Apgar score lower than 7 in the 5 th minute of life $(\mathrm{PR}=1.74)$ were determinants associated with neonatal mortality. 
Table 2 - Determinants of the intermediate and proximal dimensions of neonatal mortality in Vitória de Santo Antão from 2011 to 2018 - Recife, PE, Brazil, 2020.

\begin{tabular}{|c|c|c|c|}
\hline Determinants & PR & $95 \% \mathrm{Cl}$ & p-Value ${ }^{1}$ \\
\hline \multicolumn{4}{|c|}{$\begin{array}{l}\text { Intermediate Dimension - Behavioral } \\
\text { factors and use of services }\end{array}$} \\
\hline Type of delivery & & & 0.001 \\
\hline Caesarean & 0.83 & $0.75-0.92$ & \\
\hline Vaginal & 1 & - & \\
\hline Place of birth & & & 0.032 \\
\hline Vitória de Santo Antão & 1.12 & $1.01-1.25$ & \\
\hline Other municipalities & 1 & - & \\
\hline \multicolumn{4}{|c|}{ Proximal Dimension - Biological Factors } \\
\hline Newborn race/skin color & & & 0.035 \\
\hline Brown/Black & 1.13 & $1.00-1.29$ & \\
\hline White & 1 & - & \\
\hline Prematurity (<37 weeks) & & & 0.016 \\
\hline Yes & 1.88 & $1.79-1.97$ & \\
\hline No & 1 & - & \\
\hline Apgar score in the 5 th minute & & & $<0.001$ \\
\hline$<7$ & 1.74 & $1.67-1.82$ & \\
\hline$\geq 7$ & 1 & - & \\
\hline
\end{tabular}

\section{DISCUSSION}

In this research, neonates born via vaginal delivery, whose mothers gave birth in the municipality of the study, classified as brown/black, premature, and with an Apgar score below 7 in the fifth minute of life had a greater association with death in the first 27 days of life. The set of determinants of neonatal death after birth is complex and its impact needs to be continuously studied, because this condition is multicausal, linked to a number of socioeconomic, behavioral, and biological risk factors ${ }^{(2)}$.

Causality from biological factors is determinant in the incidence of death throughout the first year of life. However, maternal and child care and its association with social health determinants and constraints influence not only the number of these notifications, but also the access to qualified care services to attend this profile of users ${ }^{(15)}$.

In this study, the variables related to socioeconomic factors such as education, marital status, and maternal occupation, present at the most distal level of the hierarchical model, did not show a statistical association with neonatal death. These variables are related to the condition of social vulnerability to which the mother and the newborn are exposed, interfering with the access to services that ensure early prevention, diagnosis, and treatment of the main conditions involved in the causality of neonatal death ${ }^{(16)}$.

At the intermediate level, the statistical association among neonatal death, behavioral factors, and the use of health services was found in the bivariate analysis and in the multiple model for the variables type of delivery and place of birth. It was found that caesarean delivery showed an inversely proportional relationship to neonatal death in this population, in disagreement with what has been published in the literature ${ }^{(2,17)}$.

Caesarean delivery with medical indication can be configured as a protective factor for death in the neonatal period, especially in situations of obstetric emergencies and in those of extreme risk to the newborn's vitality. However, the low quality of obstetric care alone or associated with mistakes in the indication of the mode of delivery, especially when in natural births, can expose newborns to anoxia, increasing the need for surgical intervention in low-risk births ${ }^{(18-19)}$. In this study, $62.8 \%$ of neonates were premature, who could, through surgical intervention, benefit from faster neonatal care.

As for the place of birth, it was observed that neonates from the municipality under study had a higher prevalence of neonatal death when compared to other municipalities. As a professional who deals directly with care at all levels of health care, nurses shall work aiming to reach universal coverage of essential services and to articulate this with maternal and child services to minimize the pilgrimage of pregnant women in search for the place of delivery and its consequences on their health and that of the newborn ${ }^{(20)}$.

In this case, it is inferred that the regionalization of childbirth assistance contributes to access to technological devices and human resources, favoring neonatal survival ${ }^{(21)}$. In medium-sized municipalities in the Northeast, such as Vitória de Santo Antão, the structure of maternity hospitals has been identified as an element of concern in what regards emergency care for newborns, a circumstance that might directly reflect on neonatal mortality ${ }^{(22)}$.

Assistance activities in maternity hospitals shall be carried out by specialists, and shall be equal throughout the territory, which is not the case in many facilities in the Northeast region ${ }^{(23)}$, where services are concentrated in urban areas. Professional qualification and adequacy of health services for maternal and child care reduce the occurrence of unfavorable results for the newborn ${ }^{(22)}$. The lack of organization regarding the delivery and birth care network, incorporation of scientific evidence into the work processes, structure and supply in hospitals is considered an important barrier to obstetric and neonatal care.

Prenatal care and the conduction of good-quality childbirth are actions nurses can take to face and reduce neonatal mortality rates. Although the number of prenatal consultations was not included in the final model, the low number of consultations during the pregnancy cycle is associated with a negative child health outcome, as it reflects the inadequacy in health service coverage $^{(14,24)}$. Prenatal care, one of the activities developed by nurses in the Family Health Strategy, is recognized as a safe practice for maternal and child health, capable of preventing the determinants associated with neonatal death.

In the proximal dimension, the variable race/brown/black skin color was thirteen times more associated with neonatal death in the municipality studied. Issues related to ethnicracial inequality reveal disparities that still exist within the various social segments, showing the need for investments in basic social sectors ${ }^{(25-26)}$. The brown or black color accounted for $79.6 \%$ of the study sample, a finding also present in other investigations that, massively, reveal higher values of Child 
Mortality Rate (CMT) in black, brown, and indigenous children, even after statistical adjustments for covariates, such as low weight and socioeconomic status ${ }^{(17,27-28)}$.

The neonate gestational age was also identified as an association factor with death in this study. In the population studied, most neonates were less than 37 weeks of gestational age, with emphasis on newborns with less than 28 weeks of gestation, a group identified by the literature as having the greatest association with early infant death ${ }^{(24,29)}$.

Apgar score, which quantifies the vitality conditions of the child's birth, has a strong association with early infant death ${ }^{(16,30)}$. In this study, an Apgar score below 7 was found in the first minute in $53.3 \%$ of infant deaths. Apgar results work as an excellent prognostic marker for mortality from perinatal asphyxia ${ }^{(31)}$, a condition that contributes significantly to early infant death ${ }^{(32)}$.

Although the number of deaths in children under 1 year has decreased in the last three decades in Brazil, in some municipalities in the Northeast the percentage of deaths is still far from what is recommended by the Ministry of Health. The investigation of these deaths is, in most cases, associated with maternal causes, making it difficult to carry out studies focused on the age group of children under 27 days. Thus, due to the availability of updated municipal databases, the main limitations of the study are those inherent to research using secondary databases. In addition, the information presented herein should be viewed with consideration for other socioeconomic and cultural realities that directly influence the birth process. Although the municipality of the study is part of the state network of care for labor and delivery, the need for further studies that also consider other locations is highlighted.

One believes that this study could contribute to the knowledge of the factors associated with neonatal death and support the planning of actions aimed at improving health care for the woman and the newborn, resulting in a reduction in neonatal mortality rates.

\section{CONCLUSION}

Neonatal mortality was determined by factors such as: type of delivery, place of birth, brown/black newborn race/ skin color, prematurity, and Apgar score $<7$ at the 5th minute of life. The results show that neonatal deaths are related to biological characteristics and access to health services. Given this context, health professionals and managers can use the information available in their bases for situational mapping and planning of health intervention actions with a greater emphasis on good care practices in childbirth, aiming to reach government proposals for infant and neonatal mortality rates control in its territory.

\section{RESUMO}

Objetivo: Analisar os determinantes associados à mortalidade neonatal em um município da Zona da Mata pernambucana. Método: Estudo transversal e analítico, realizado em Vitória de Santo Antão, Pernambuco. Foram analisados todos os óbitos infantis notificados pelo município no Sistema de Informação sobre Mortalidade entre os anos de 2011 a 2018. Os dados foram categorizados e organizados em três dimensões para serem submetidos à estatística descritiva, bivariada e regressão de Poisson hierarquizada com variância robusta. Foram estimadas as razões de prevalência, considerando-se como significantes variáveis com $\mathrm{p}<0,05$. Resultados: Os determinantes associados ao óbito neonatal foram: parto cesáreo (RP 0,83; IC95\% 0,75-0,92), nascimento no próprio município (RP 1,12; IC95\% 1,01-1,25), raça/cor do recém-nascido parda e preta (RP 1,13; IC95\% 1,00-1,29), prematuridade (RP 1,88; IC95\% 1,79-1,97) e Escore de Apgar < 7 no quinto minuto (RP 1,74; IC95\%1,67-1,82). Conclusão: Características biológicas como raça/cor parda e preta, prematuridade e Escore de Apgar $<7$ no $5^{\circ}$ minuto após o nascimento, bem como o acesso aos serviços de saúde, como nascer no próprio município e não nascer de parto cesáreo, foram determinantes associados à mortalidade neonatal.

\section{DESCRITORES}

Mortalidade Infantil; Fatores de Risco; Enfermagem Neonatal; Enfermagem Pediátrica; Sistemas de Informação.

\section{RESUMEN}

Objetivo: Analizar los determinantes asociados a la mortalidad neonatal en un municipio de la Zona da Mata de Pernambuco. Método: Estudio transversal y analítico, realizado en Vitória de Santo Antão, Pernambuco. Todas las muertes infantiles reportadas por el municipio en el Sistema de Información de Mortalidad entre 2011 y 2018 fueron analizadas. Los datos fueron categorizados y organizados en tres dimensiones para ser sometidos a estadística descriptiva, bivariada y regresión de Poisson con varianza robusta. Razones de prevalencia fueron estimadas, considerando como significativas las variables con $\mathrm{p}<0.05$. Resultados: Los determinantes asociados a la muerte neonatal fueron: parto por cesárea (RP 0,83; IC 95\% 0,75-0,92), nacimiento en la propia ciudad (RP 1,12; IC 95\% 1,01-1,25), raza/color del recién nacido parda y negra. (RP 1,13; IC del 95\% 1,00-1,29), prematuridad (RP 1,88; IC del 95\% 1,79-1,97) y puntuación de Apgar < 7 en el quinto minuto (RP 1,74; IC del 95\% 1,67-1,82). Conclusión: Características biológicas como raza/ color parda y negra, prematuridad y puntaje de Apgar $<7$ en el 50 minuto posparto, así como el acceso a servicios de salud, como nacer en el propio municipio y no nacer por cesárea fueron determinantes asociados con la mortalidad neonatal.

\section{DESCRIPTORES}

Mortalidad Infantil; Factores de Riesgo; Enfermería Neonatal; Enfermería Pediátrica; Sistemas de Información.

\section{REFERENCES}

1. Martins PCR, Pontes ERJC, Higa LT. Convergência entre as taxas de mortalidade infantil e os índices de desenvolvimento humano no Brasil no período de 2000 a 2010. Interações. 2018;19(2):291-303. doi: https://doi.org/10.20435/inter.v19i2.1552

2. Sleutjes FCM, Parada CMGL, Carvalhaes MABL, Temer MJ. Risk factors for neonatal death in an inland region in the State of São Paulo Brazil. Ciênc Saúde Coletiva. 2018;23(8):2713-20. doi: http://dx.doi.org/10.1590/1413-81232018238.15142016

3. Hug L, Alexander M, You D, Alkema L. National, regional, and global levels and trends in neonatal mortality between 1990 and 2017 , with scenario-based projections to 2030: a systematic analysis. Lancet. 2019;7(6):e710-20. doi: https://doi.org/10.1016/S2214-109X(19)30163-9. 
4. United Nations Children's Fund. Levels and trends in child mortality: report 2019 [Internet]. New York: UNICEF, 2019 [cited 2019 June 12]. Available from: https://data.unicef.org/resources/levels-and-trends-in-child-mortality/

5. World Health Organization. Estimates developed by the UN Inter-agency Group for Child Mortality Estimation United. Geneva: WHO; 2015.

6. You D, Hug L, Ejdemyr S, Beise J. Levels and trends in child mortality: report 2015. New York: United Nations Inter-agency Group for Child Mortality Estimation; 2015.

7. Castro ECM, Leite AJM, Guinsburg R. Mortality in the first $24 \mathrm{~h}$ of very low birth weight preterm infants in the Northeast of Brazil. Rev Paul Pediatr. 2016;34(1):106-13. doi: https://doi.org/10.1016/j.rppede.2015.12.008

8. Leal MC, Szwarcwald CL, Almeida PVB, Aquino EML, Barreto ML, Barros F, et al. Reproductive, maternal, neonatal and child health in the 30 years since the creation of the Unified Health System (SUS). Ciênc Saúde Coletiva. 2018;23:1915-28. doi: https://doi.org/10.1590/141381232018236.03942018

9. Lansky S, Friche AAL, Silva AAM, Campos D, Bittencourt SDA, Carvalho ML, et al. Birth in Brazil survey: neonatal mortality, pregnancy and childbirth quality of care. Cad Saúde Pública. 2014;30 Suppl 1:S192-S207. doi: https://doi.org/10.1590/0102-311X00133213

10. Lima SS, Braga MC, Vanderlei LCM, Luna CF, Frias PG. Assessment of the impact of prenatal, childbirth, and neonatal care on avoidable neonatal deaths in Pernambuco State, Brazil: an adequacy study. Cad Saúde Pública. 2020;36(2):e00039719. doi: https://doi. org/10.1590/0102-311x00039719

11. Machado JC, Cotta RM, Soares JB. Reflexões sobre o processo de municipalização das políticas de saúde: a questão da descontinuidade político-administrativa. Interface. 2015; 19:159-70. doi: https://doi.org/10.1590/1807-57622013.1002

12. Mosley WH, Chen LC. An analytical framework for the study of child survival in developing countries. Popul Dev Rev. 1984;10 Suppl:25-45.

13. Maia LTS, Souza WV, Mendes ACG, Silva AGS. Use of linkage to improve the completeness of the SIM and SINASC in the Brazilian capitals. Rev Saúde Pública. 2017; 51:112. doi: https://doi.org/10.11606/S1518-8787.2017051000431

14. Garcia LP, Fernandes CM, Traebert J. Risk factors for neonatal death in the capital city with the lowest infant mortality rate in Brazil. J Pediatr. 2019;95(2):194-200. doi: https://doi.org/10.1016/j.jped.2017.12.007

15. Maia LTS, Souza WV, Mendes ACG. Individual and contextual determinants of infant mortality in Brazilian state capitals: a multilevel approach. Cad Saúde Pública. 2020;36(2):e00057519. doi: https://doi.org/10.1590/0102-311x00057519.

16. Veloso FCS, Kassar LML, Oliveira MJC, Lima THB, Bueno NB, Gurgel RQ, et al. Analysis of neonatal mortality risk factors in Brazil: a systematic review and meta-analysis of observational studies. J Pediatr. 2019;95(5):519-30. doi: http://dx.doi.org/10.1016/j. jped.2018.12.014

17. Lima JC, Mingarelli AM, Segri NJ, Zavala AA, Takano OA. Estudo de base populacional sobre mortalidade infantil. Ciênc Saúde Coletiva. 2017;22(3):931-9. doi: http://dx.doi.org/10.1590/1413-81232017223.12742016

18. Santos EP, Ferrari RAP, Bertolozzi MR, Cardelli AAM, Godoy CB, Genovesi FF. Mortality among children under the age of one: analysis of cases after discharge from maternity. Rev Esc Enferm USP. 2016;50(3):390-8. doi: http://dx.doi.org/10.1590/S0080-623420160000400003

19. Sanders LSC, Pinto FJM, Medeiros CRB, Sampaio RMM Viana RAA, Lima KJ. Infant mortality: analysis of associated factors in a capital of Northeast Brazil. Cad Saúde Coletiva. 2017;25(1): 83-9. doi: https://doi.org/10.1590/1414-462x201700010284

20. Parada CMGL. Women's health during pregnancy, childbirth and puerperium: 25 years of recommendations from international organizations. Rev Bras Enferm. 2019;72 Suppl 3:1-2. doi: https://doi.org/10.1590/0034-7167-2019-72suppl301

21. Leal MC, Theme-Filha MM, Moura EC, Cecatti JG, Santos LMP. Prenatal and childbirth care for women using the public health system resident in Amazonia Legal and the Northeast Region of Brazil 2010. Rev Bras Saude Mater Infant. 2015;15(1):91-104. doi: https://doi. org/10.1590/S1519-38292015000100008

22. Bittencourt SDA, Reis LGC, Ramos MM, Rattner D, Rodrigues PL, Neves DCO, et al. Structure in Brazilian maternity hospitals: key characteristics for quality of obstetric and neonatal care. Cad Saúde Pública. 2014;30 Suppl 1:208-19. doi: https://doi.org/10.1590/0102$311 \times 00176913$

23. Furtado EZL, Gomes KRO, Gama SGN. Access to childbirth care by adolescents and young people in the Northeastern region of Brazil. Rev Saúde Pública. 2016;50(23). doi: https://doi.org/10.1590/S1518-8787.2016050005396.

24. Gaíva MAM, Lopes FSP, Ferreira SMB, Mufato LP. Óbitos neonatais de recém-nascidos de baixo peso ao nascer. Rev Eletr Enf [Internet]. 2018 [citado 2020 mar. 03];20(18):1-10. Disponível em: http://docs.bvsalud.org/biblioref/2018/11/964704/v20a18.pdf

25. Gava C, Cardoso AM, Basta PC. Infant mortality by color or race from Rondônia, Brazilian Amazon. Rev Saúde Pública. 2017;51(35). doi: https://doi.org/10.1590/S1518-8787.2017051006411

26. Picoli RP, Cazola LHO, Nascimento DDG. Child mortality and classification of its preventability by skin color or ethnicity in Mato Grosso do Sul, Brazil. Ciênc Saúde Coletiva. 2019;24(9):3315-24. doi: https://doi.org/10.1590/1413-81232018249.26622017

27. Drumond E, Abreu DM, Machado C, Gomes F, França E. Racial disparities and avoidable infant mortality in a city of southeastern Brazil, 2001-09. J Trop Pediatr. 2013;59(1):23-8. doi: https://doi.org/10.1093/tropej/fms039

28. Pereira MUL, Lamy Filho F, Anunciação OS, Lamy ZC, Gonçalves LLM, Madeira HGR. Óbitos neonatais no município de São Luís: causas básicas e fatores associados ao óbito neonatal precoce neonatal. Rev Pesq Saúde. 2017;18(1):18-23.

29. Kropiwieca MV, Franco SC, Amaral AR. Factors associated with infant mortality in a Brazilian city with high human development index. Rev Paul Pediatr. 2017;35(4):391-8. doi: http://dx.doi.org/10.1590/1984-0462/;2017;35;4;00006

30. Brasil TB, Pinto FJM, Sampaio RMM, Viana RAA, Lima KJ, Camelo IM, et al. Fatores associados à mortalidade neonatal com ênfase no componente da atenção hospitalar ao recém-nascido. Arq Catarin Med. 2018;47(2):70-86.

31. Cnattingius S, Norman M, Granath F, Petersson G, Stephansson O, Frisell T. Apgar Score Components at 5 Minutes: risks and prediction of neonatal mortality. Paediatr Perinat Epidemiol. 2017;31(4):328-37. doi: 10.1111/ppe.12360 
32. Almeida MFB, Kawakamia MD, Moreira LMO, Santos RMV, Anchieta LM, Guinsburg R. Early neonatal deaths associated with perinatal asphyxia in infants $\geq 2500 \mathrm{~g}$ in Brazil. J Pediatr. 2017;48(1):1-9. doi: http://dx.doi.org/10.1016/j.jped.2016.11.008

Financial support:

Coordenação de Aperfeiçoamento de Pessoal de Nível Superior (CAPES). Masters Scholarship in the Social Demand Program. This study was financed in part by the Coordenação de Aperfeiçoamento de Pessoal de Nível Superior - Brasil (CAPES) - Finance Code 001. 